\title{
The Impact of Trade War toward Against Indonesian Agriculture Export Products Product
}

\author{
Syahrul Ganda Sukmaya ${ }^{1, *}$, Saptana Saptana ${ }^{2}$ \\ ${ }^{1}$ Universitas Perjuangan Tasikmalaya, Departement of Agribusiness, Tasikmalaya 46115, Indonesia \\ ${ }^{2}$ Indonesian Centre for Agricultural Socio Economic and Policy Studies, Bogor, 16124, Indonesia
}

\begin{abstract}
In recent history, the ongoing trade war between the United States and China is unparalleled. This research looks at the impact of trade wars on Indonesian agricultural products' competitiveness and export performance. The methods used for this study are NRCA, EPD and CMSA. We find that conditions of the trade war between China and the US affect the competitiveness and competitiveness of Indonesian agricultural products in the destination countries. The impact of the trade war conditions on the competitiveness of Indonesian agricultural products compared to China and their export to the United States. Indonesia's agricultural exports during the trade war to China's and US destination countries are: HS 01, HS 04, HS 08, HS 12 and HS 18. Indonesian agricultural exports to China and the US are influenced primarily by the increase in global demand and the composition of competitiveness.
\end{abstract}

\section{Introduction}

Since 2013, a heated US-China trade rivalry has led to trade war. This trade war was waged by restricting both countries' exports of goods and services by applying high tariffs and other trade policies such as quotas, food safety certifications and others. The trade war began in June 2016, when President Trump attacked China's unfair trade policies [1]. This situation received a response from the Chinese state by retaliating against imposing tariffs on U.S. imported products [2]. This continues to reciprocate and continues to this day, ultimately affecting other countries, including Indonesia.

At the beginning of 2018 , the United States enforced Section 232 of the 1962 Trade Expansion Act (alleging a national security threat) to raise tariffs on steel and aluminum goods, which sparked U.S. trade tensions with major steel and aluminum exporters, including China. Some of these conflicts, such as those between the United States and Canada and Mexico, have now been settled by arbitration. Meanwhile, US trade tensions with China have increasingly developed into a full-blown trade war. Following Section 301 (unfair trade) inquiries, the United States raised tariffs on vast volumes of Chinese products. China was able to retaliate proportionately in early rounds, but soon ran out of US exports to add tariffs due to its huge trade surplus with the United States [3]. As of the fall of 2019, more than $90 \%$ of goods in the six-digit Harmonized Framework (HS6) Classification Stage is subject to

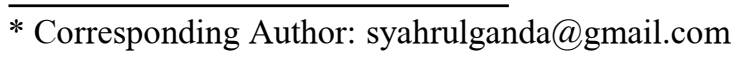


tariff rises in one or both countries. The step one trade agreement signed by the two countries in January 2020 slows down the speed of the trade war by reducing some of the previous tariff increases and withdrawing the possibility of tariff increases. However, the step one tariff concessions are small and the course of trade talks is unclear [4].

The trade war between the two largest economies in the world is expected to influence exporting countries, including Indonesia. Indonesia is also suspected of being affected by commercial warfare and is the exporter and importer of both major countries. Unabsorbed Chinese export products to the US are transferred to other countries, one of which is large- scale Indonesia. This is reflected in the growth in Indonesia's import value to Chinese products from 2015-18 while US imports tend to stagnate (Figure 1).

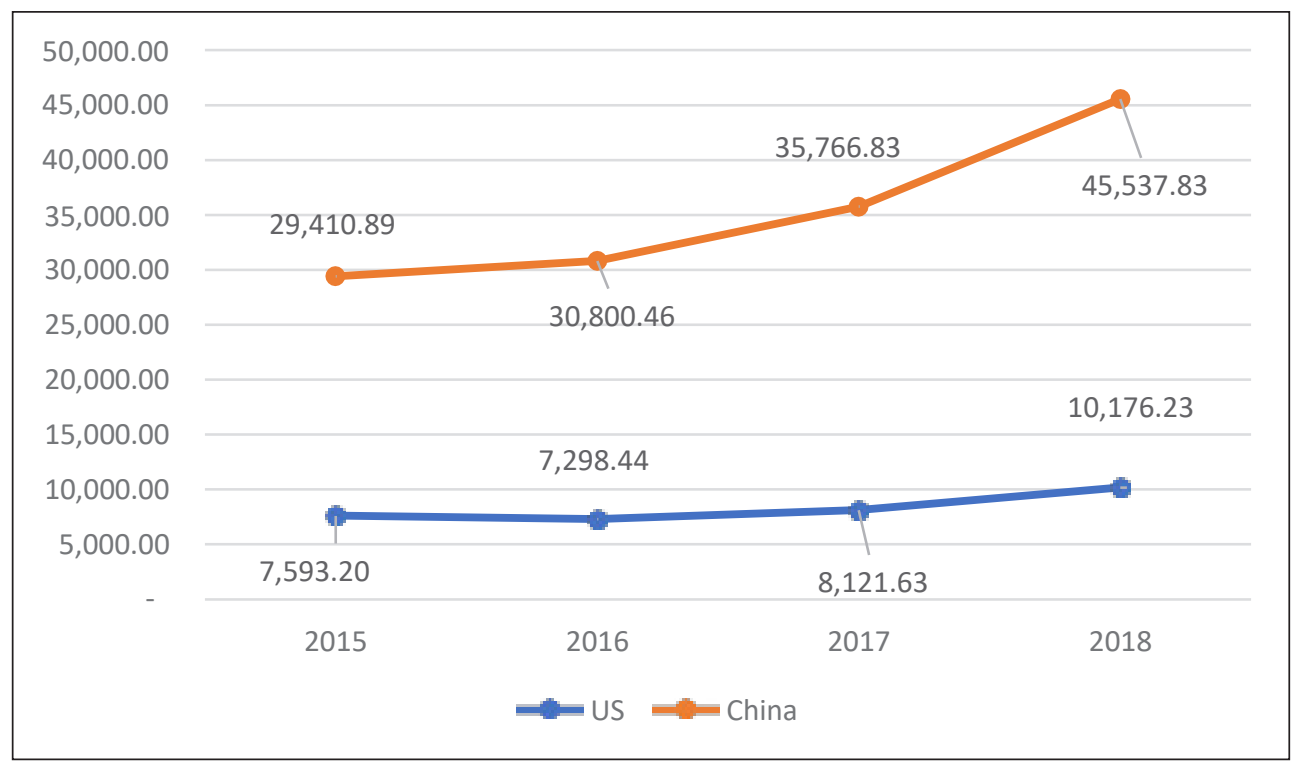

\section{Source: [5]}

Fig.1. Import value of China and US to Indonesia from 2015 to 2018 (in billion US\$).

Indonesia's trade balance has also been affected by uncertain global market conditions. Growth of the trade balance declined in 2018 following an upward trend in 2015-2017 (Figure 2). The trade balance in Indonesia decreased in 2018 by $\$-20,542.3$ million over the previous year. This decrease was due to high oil and gas imports from Indonesia, while non- oil and gas exports were unable to cover the deficit due to declining performance due to changing world markets. Non-oil and gas exports fell by -80 percent in 2018 compared to the previous year. This is supposed to be the result of a trade war between China and the US. Trade wars and United States trade policies have disturbed Indonesia's exports to the country and affected the trade balance. 


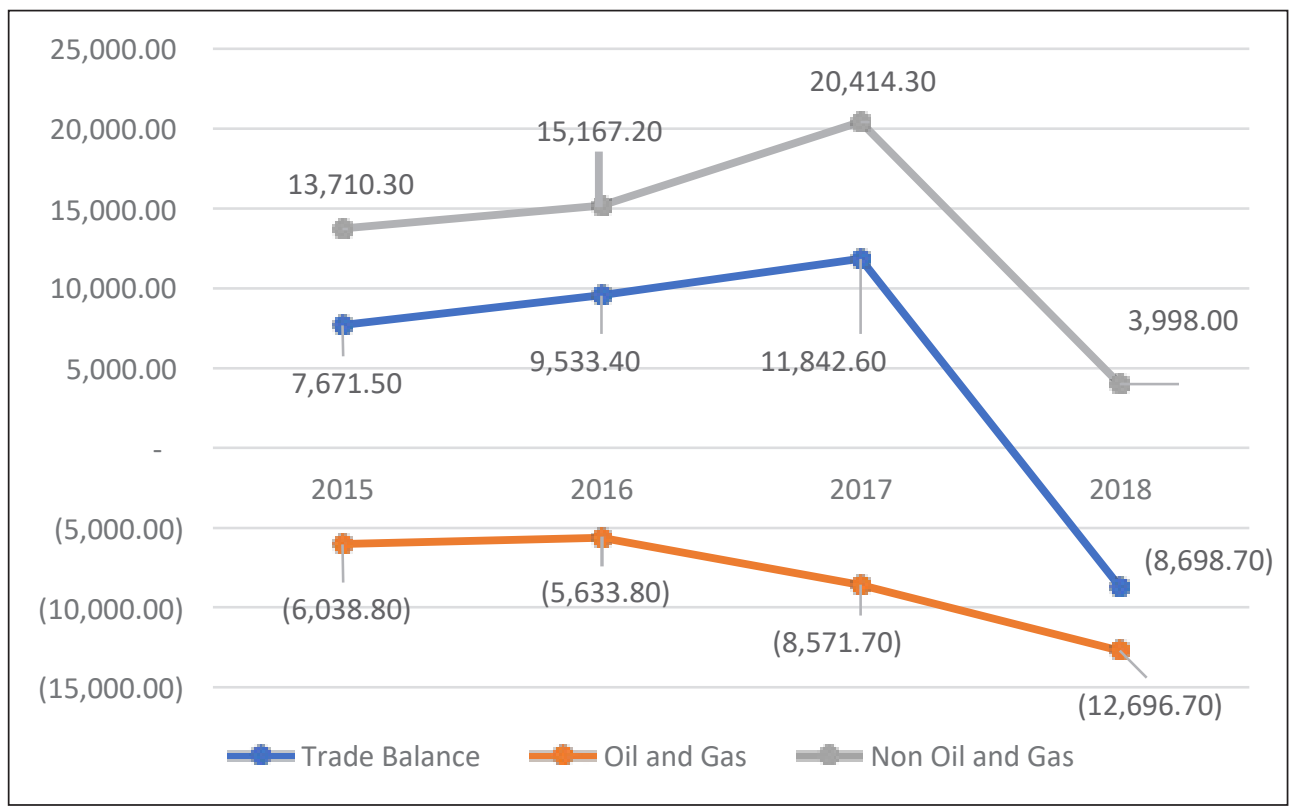

\section{Source: [5].}

Fig. 2. Trade balance of Indonesia in 2015 to 2018 (in billion US\$).

Agricultural products are one of Indonesia's main sources of export revenue. Superior products for Indonesia's export to destination countries like China and America are agricultural products, such as vegetable oil, natural rubber, fishery products, and other. Indonesia's export performance of agricultural products has been down from 2015 to 2018 (Figure 3). The deterioration in agricultural export performance is expected because the global market conditions recovered from the 2008 crisis and the trade war between China and the United States.

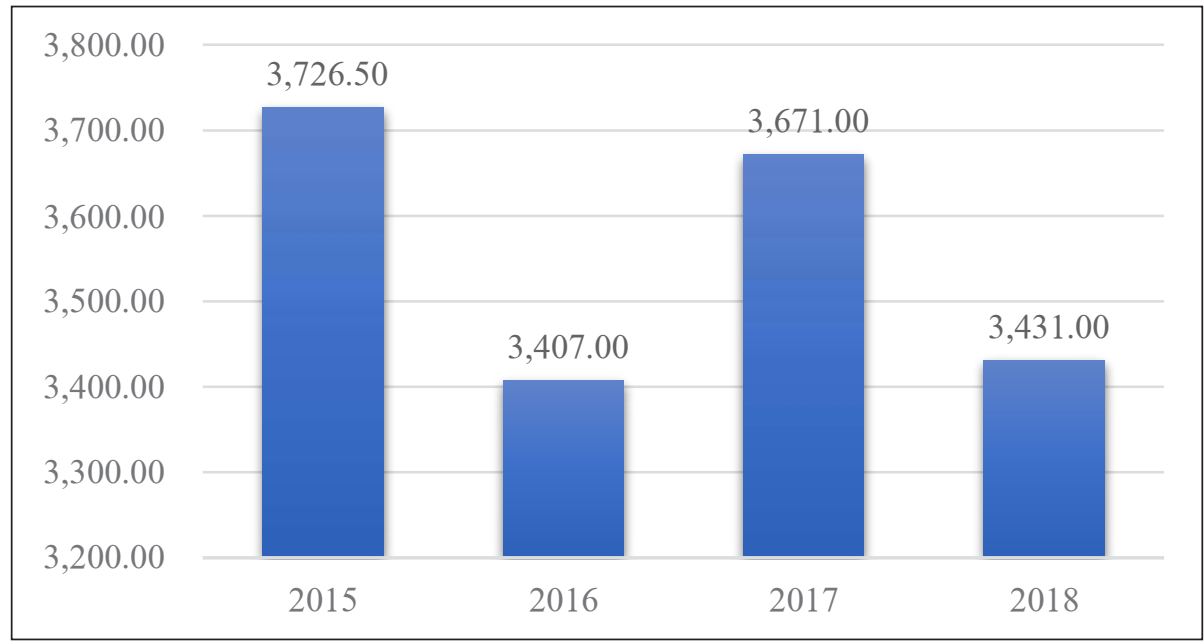

\section{Source: [5]}

Fig. 3. Growth of export Indonesian agricultural products from 2015 to 2018 (in billion US\$). 
The trade war has interested researchers in reviewing the competitiveness and performance of agricultural exports to China and the United States' main export destinations. Competitiveness of products is indispensable in order to compete on the destination market. An export performance review is needed to examine the impact of trade wars on Indonesia's flagship commodity exports and what factors affect them.

\section{Methodology}

This study used time series data from 1999-2018 on the export of the Indonesian flagship products. Agricultural product flagship data reported on the basis of 2 digits using HS code. Table 1 shows the agricultural flagship products reviewed in this study. NRCA (Normative Revenue Comparative Advantage) index, CMSA (Constant Market Share Analysis) and EPD (Export Product Dynamics) are the analytical tools used in this research. The 1999-2018 time sequence data is divided into 4 periods to see the differences in each condition. Periode 1 is from 1999-2003, periode 2 from 20042008, periode 3 from 2009-2013, and periode 4 from 2014-2018.

Table 1. HS Code, Commodity and Data Source of Indonesian Agricultural Product

\begin{tabular}{|c|c|c|}
\hline HS Code & Commodity & Data Source \\
\hline 01 & Animals; live & UN COMTRADE \\
\hline 03 & $\begin{array}{l}\text { Fish and crustaceans, molluscs and other aquatic } \\
\text { invertebrates }\end{array}$ & UN COMTRADE \\
\hline 04 & $\begin{array}{l}\text { Dairy produce; birds' eggs; natural honey; edible } \\
\text { products of animal origin, not elsewhere specified or } \\
\text { included }\end{array}$ & UN COMTRADE \\
\hline 07 & Vegetables and certain roots and tubers; edible & UN COMTRADE \\
\hline 08 & $\begin{array}{l}\text { Fruit and nuts, edible; peel } \\
\text { of citrus fruit or melons }\end{array}$ & UN COMTRADE \\
\hline 09 & Coffee, tea, mate and spices & UN COMTRADE \\
\hline 12 & $\begin{array}{l}\text { Oil seeds and oleaginous fruits; miscellaneous grains, } \\
\text { seeds and fruit, industrial or medicinal plants; straw } \\
\text { and fodder }\end{array}$ & UN COMTRADE \\
\hline 14 & $\begin{array}{l}\text { Vegetable plaiting materials; vegetable productsnot } \\
\text { elsewhere specified or included }\end{array}$ & UN COMTRADE \\
\hline 18 & Cocoa and cocoa preparations & UN COMTRADE \\
\hline 24 & Tobacco and manufactured tobacco substitutes & UN COMTRADE \\
\hline
\end{tabular}

Source: [6]

CMSA is used to measure the market share of Indonesia's leading agricultural commodities on the destination market. CMSA is a constant market share analysis. The NRCA index is used, because compared to other competitive index measurements it can be considered quite complete in measuring the competitive level of commodities and countries. Because of its consistent measured results and more comprehensive results in achieving the results, the NRCA Index has an advantage over other competitiveness indicators. In order to be aware of a market attractiveness and business strength information, the EPD has two components associated to the EPD matrix.

\subsection{Normalize Revealed Comparative Advantage (NRCA)}

Normalize Revealed Comparative Advantage (NRCA) in order to address the problem of BRCA limitations and some of the alternative RCA indexes. NRCA has attributes that can indicate the rank and comparable in comparative advantages across commodities, countries and periods. The pattern of trade in a country is expected to be shown, allowing for the identification of the types of goods with good potential in a market and at a specific time. The NRCA index value is zero or neutral for every commodity in every country as a whole. This corresponds to the assumption that no country has a comparative benefit for all commodities. NRCA is seen as consistent when 
measuring a symmetrical, a country- and commodity-based additive comparable advantage across countries, commodities and time. NRCA can therefore be used for the analysis of time series and comparative analyzes of the comparative advantage of the panel data between countries [7]. This is the NRCA equation:

$$
\mathrm{NRCA}_{\mathrm{j}}^{\mathrm{i}} \equiv \Delta \mathrm{E}_{\mathrm{j}}^{\mathrm{i}} / \mathrm{E}=\mathrm{E}_{\mathrm{j}}^{\mathrm{i}} / \mathrm{E}-\mathrm{E}_{\mathrm{j}} \mathrm{E}^{\mathrm{i}} / \mathrm{EE}
$$

As per Eq. (1), NRCAij > 0 (or NRCAij < 0) shows a country I export commodity $\mathrm{j}$ (Eij) is more (or less) than its neutral level comparative advantage (Eij), meaning that country I have a comparable advantage (or disadvantage) in commodity $\mathrm{j}$. The bigger (or smaller) the NRCAij value, the more powerful would be the comparative advantage. As a relative concept is a comparative advantage, the interpretation of the magnitude of NRCA is more meaningful as far as the comparative advantage is concerned in a comparative context. For example, NRCAij $=0.01$, and NRCAik $=0.05$ means that the comparable advantages in commodities $\mathrm{k}$ are five times the relative strength of country $i$ in commodity $j$.

\subsection{Export Product Dynamics (EPD)}

Export Product Dynamics (EPD) is a method for analyzing and identifying highly competitive products or commodities with fast export growth [8]. If export growth is above the average of the world during a given period, the commodity will grow above average and become an increasingly important source of revenue for the state [9]. EPD is the most suitable way to identify useful products based on an increase in exports over a given period. It is said that a commodity is a dynamic global commodity if its market share increases faster than other products [10]. EPD describes the position of the export growth of a product through its overall export share or market attractiveness and product shipping or business strengths. The combination of these two components results in the position of the product in four categories that you wish to analyze. The four categories of the export market share in world trade or market attractions are Rising Star, Falling Star, Lost Opportunity and Retreat in Figure 2, which has a quadrant shape with the X Axis. The Y axis represents an increase in world trade or business strength information for such products.

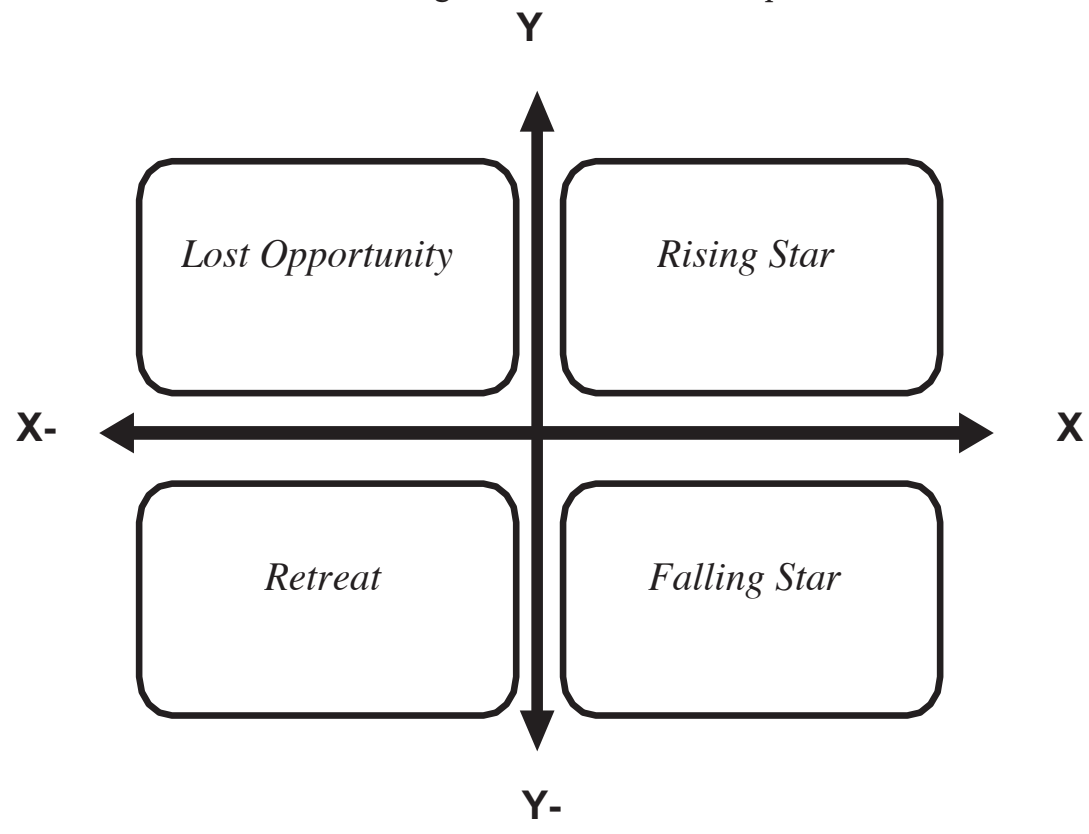

Source: [11]

Fig. 4. Position competitiveness of products with EPD method 
The formula for the calculation of this EPD is as follows:

$\mathrm{X}$-axis: Growth of business strength or export market share:

$$
\frac{\sum_{\mathrm{t}-1}^{\mathrm{t}}\left[\left(\frac{\mathrm{x}_{\mathrm{ij}}}{\mathrm{w}_{\mathrm{ij}}}\right)_{\mathrm{t}} \times 100 \%-\left(\frac{\mathrm{x}_{\mathrm{ij}}}{\mathrm{w}_{\mathrm{ij}}}\right)_{\mathrm{t}-1} \times 100 \%\right]}{\mathrm{T}-1}
$$

Y-axis: Growth market appeal or market share of the product:

$$
\frac{\sum_{t-1}^{t}\left[\left(\frac{x_{t}}{w_{t}}\right)_{t} \times 100 \%-\left(\frac{x_{t}}{w_{t}}\right)_{t-1} \times 100 \%\right]}{T-1}
$$

Where (in this case):

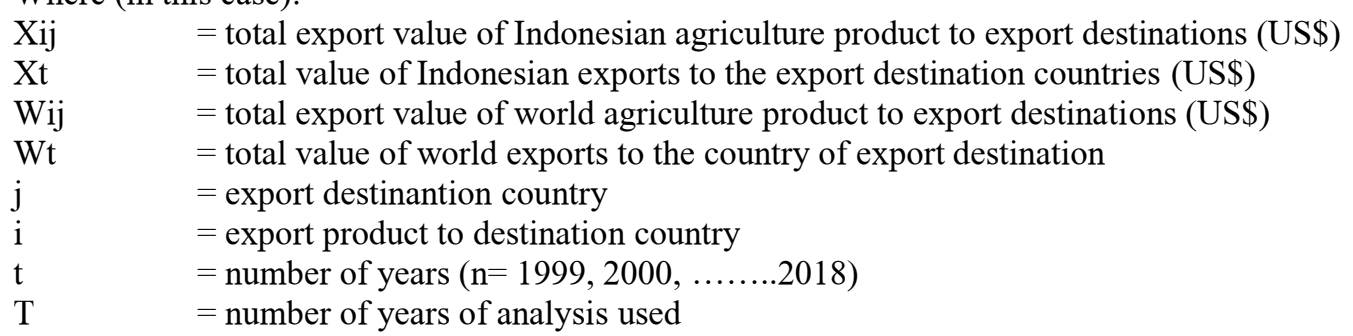

The position of Rising Star is characterized by a market share acquisition of the fast- growing products of the country. While the lost position of opportunity shows a decrease in market share of dynamic products, the position or condition most unwanted. This is because the country loses its export share opportunity on the world market for dynamic commodities. Star falling is also an unwanted position, but unlike the position of Lost Opportunity. This is because its market share increases in Falling Star's position, even if it isn't in the world market for dynamic products. In the meantime, the position of Retreat means that the product is no longer wanted on the market. But if the movement away from the stagnant product and is close to improving dynamic products, it can be re-desired.

\subsection{Constant Market Share Analysis (CMSA)}

The CMS model is the popular way to measure a country's export performance. Tyszynsky Baldwin, Spiegeeglas and Naya [12-14] have first been used in this model. Leamer and Stern [15] have improved the model. The CMS model allows us to break down a country's export growth into four effects between two times. These effects include the World Demand Effect (WDE), the Composition of Competitiveness Effect (CCE), and Competitiveness Effect (CE). The difference between export growth and export growth is explained on the assumption that each export flux increases according to the import market, i.e. that the country-centered share of each commodity remains constant on every market. Exports are differentiated by commodity and market requirements. 
The formula for the calculation of this CMSA is as follows:

$$
X i 2-X i 1=m X i 1+\{(m i-m) 1\}+\{X i 2-X i 1-m i X i 1\}
$$

Where (in this case):

$\begin{array}{ll}X i 1 & =\text { Export of Indonesian agricultural products to the world in the period } 1 \\ X i 2 & =\text { Export of Indonesian agricultural products to the world in the period } 2 \\ \mathrm{~m} & =\text { Growth in exports of the world's agricultural products } \\ \mathrm{mi} & =\text { Growth in commodity exports of the world's agricultural products } \\ (1) & =\text { World Demand Effect (WDE) } \\ (2) & =\text { the Composition of Competitiveness Effect (CCE) } \\ (3) & =\text { Competitiveness Effect (CE) }\end{array}$

\section{Result and Report}

Table 2 is the result of analysis on the competitiveness, position and market share of Indonesian agricultural export products to the Chinese market from periods 1 to 4 . The development of competitiveness, position and market share of Indonesian agricultural products experienced an increasing trend from the period 1 to 4 to the Chinese market. Period 1 to bring the competitiveness of some Indonesian agricultural products to the Chinese market is already competitive, but it has not been attractive to consumers of the Chinese market. The lack of consumer interest in the Chinese market is indicated by the large number of agricultural products exported by Indonesia into the category of "Retreat" and "Falling Star" in the 1st period. The increase in competitiveness and market interest of Indonesian agricultural products to the Chinese market occurred from the 2 nd to the 4 th period. The increase was demonstrated by the increasing position of Indonesian agricultural products into the "Rising Star" category in the period 2 to 4.

The competitiveness of Indonesian agricultural export products to the Chinese market is indicated by NRCA value. The NRCA's positive value indicates that the agricultural product has competitiveness in the Chinese market. The competitiveness of Indonesian products to the Chinese market is relatively stable from the period 1 to 4 , as seen from the same number of products that have competitiveness from the period 1 to 4 . Export products that have competitiveness in the Chinese market include HS 03, HS 07, HS 09, HS 14, and HS 18. The high competitiveness of Indonesian agricultural products to the Chinese market is one of the factors caused by the existence of trade cooperation between Indonesia and China [16-19].

The growing competitiveness of Indonesia's agricultural export products can be seen using EPD analysis. EPD analysis can identify the speed of export growth of a commodity between times in a particular market. The speed of growth of commodity exports in the destination market is a sign that the product is desired by consumers. The dynamic development of Indonesian agricultural export products in the Chinese market is excellent. In the 1st period it was seen that Indonesia's agricultural export products were not in demand by the Chinese market, characterized by the categories of "retreat" and "falling star" for agricultural export products. However, in the second period there were significant developments in the export of Indonesian agricultural products. In the 2 nd period, a lot of Indonesian agricultural products fall into the category of "rising star". In the $3 \mathrm{rd}$ and 4 th periods, where there was a crisis in the global market and trade war, the export growth of Indonesian agricultural products was still quite good with the number of export products that fall into the category of "Rising Star" [20]. Based on this, it can be concluded that the export of Indonesian agricultural products to the Chinese market is quite good and stable despite the global crisis and trade war.

The growth of market share of Indonesian agricultural export products to China can be identified by CMSA method. CMSA assists in analyzing the factors that influence the growth of exports to the destination country. The growth of Indonesia's agricultural products exports to the Chinese market is caused by the effects of world growth, as seen from the large WDE value of each export commodity from the period 1 to 4 compared to other securities in CMSA. Nigraningrum et al, Ramdhani and Santoso [21-22] states that Indonesia's agricultural export 
products are competitive in the global market due to the growth of the global market.

Table 3 shows the results of analysis on the competitiveness, position, and market share of Indonesian export products to U.S. countries. The competitiveness of agricultural export products is indicated by the NRCA value, then the position of competitiveness is indicated by the EPD category, and the market share of agricultural products is indicated by the CMSA value. In general, from periods 1 to 4 , the competitiveness conditions of Indonesian agricultural products to the U.S. market are very volatile. This is demonstrated by the large number of agricultural products whose competitiveness, position, and market share decreased when there was economic turmoil in the U.S. in the 1 st and 3rd periods, then began to rise in the 4th period.

The competitiveness of Indonesian agricultural products in the U.S. market experienced a downward trend from the period 1 to 4 , indicated by the decreasing number of commodities whose NRC value is positive. In the period 1 and 2 the number of agricultural products that have competitiveness as much as 5 products, dropped to 4 products only in the period 3 and 4 . This decrease was caused by the U.S. economic condition in the period 3 and 4 is experiencing a crisis, thus decreasing the demand for imported products and protection of domestic products that have an impact on the competitiveness of Indonesian agricultural products [23].

The competitive position of Indonesian agricultural products to the U.S. market can be seen through EPD analysis. EPD analysis can show the speed of development of product exports between times. Based on the EPD analysis, it can be seen that the development of Indonesia's agricultural exports is very volatile. In the 1st period, the export of Indonesian agricultural products in the U.S. market has not developed well and is attractive to consumers so that all export products fall into the category of "retreat" and "falling star". Then in the 2nd period the development of Indonesian agricultural exports to the U.S. market was very good, it was shown by the number of Indonesian agricultural products that fall into the category of "rising star" such as HS 03, HS 04, HS 08, HS 09, HS 18 and HS 24. However, in the 3rd period where there was a global crisis that caused the decline of the U.S. economy resulted in a decrease in the growth of Indonesian product exports to the U.S. Then, in the 4th period there was an improvement in the economy in the U.S. which again increased the demand for Indonesian agricultural products so that it returned to growth. In the 4th period there was a trade war between the U.S. and China, which at this time has not had a significant impact on the growth of Exports of Indonesian agricultural products to the U.S [24].

CMSA assists in analyzing the factors that influence the growth of exports to the destination country. The growth of Indonesia's agricultural products exports to the U.S. market is due to the effects of world growth and the composition of the competitiveness effect. In the period 1 to 3 the growth of Exports of Indonesian agricultural products to the U.S. market was caused by the effects of world growth (WDE), while pariode 4 was caused by the effect of competitiveness composition (CCE). This can be seen from the amount of WDE in the period 1 to 3 for each commodity (table 3 ) and CCE value for period 4 in each commodity (table 3).

Tables 2 and 3 show the competitiveness of Indonesia's agricultural export products on the destination markets of China and the US. Table 1 demonstrates the competitiveness in the Chinese market of Indonesian agricultural products. Table 2 shows Indonesian agricultural products' competitiveness on the US market.

Based on the NRCA method of competitiveness measurement, there are 5 (five) agricultural commodities that have competitiveness over a period of 1 to 4 periods. Agricultural export commodities can be said to be competitive if they have an NRCA value greater than zero. The five agricultural export commodities that are competitive on the Chinese market are HS 03 (fish and crustaceans, molluscs and other aquatic inverterbrates), HS 07 (vegetables and certain root and tubers; edible), HS 09 (coffee, tea, mate and spices), HS 14 (vegetable plaiting materials) and HS 18 (cocoa and cocoa preparations). There are four export commodities in the United States export market that are competitive, namely HS 03 (fish and crustaceans, molluscs and other aquatic inverterbrates), HS 09 (coffee, tea, mate and spices), HS 18 (cocoa and cocoa preparations) and HS 24 (tobacco and manufactured tobacco substitutes).

Indonesia's agricultural export products have become more competitive in the main destinations of China than the US. This is shown by the large number of export commodities from 
agriculture in the category of the "Rising Star" from 1999-2018 (Table 2). The competitiveness position of agricultural exports in the destination country was in the category "Falling Star" and "Retreat" during period 1 (1999-2003). This means that the market not have intention to Indonesian agricultural product in period 1. The competitiveness position of agricultural export products increased considerably during the period 2 to 4 . This increased competitiveness is reflected in the number of agricultural export products in the "Rising Star" category, both in China and the US, in export destination countries. The competitiveness of Indonesian agricultural export products decreased during the third period (2009-2013). This decrease is seen from the number of agricultural export commodities in the "Lost Opportunity" category. The conditions of "Lost Opportunity" indicate a decrease in the market share of Indonesian agricultural export products in the target country during the period of 3 . The competitiveness positions of Indonesian agricultural products in the destination countries of China and the United States increased in period 4 or during the period of trade war. During the trading war, Indonesia's share of the export market of agricultural products was strongly felt in comparison to the Chinese markets in the United States.

Factors that promote the competitiveness of agricultural export products in the destination markets of China and the United States can be identified by the cms method. The growth in global demand and the composition of competitiveness for HS 03, HS 09 and HS 14 commodities, the impact of competitiveness and increased global demand for HS 07 commodities and increased global demand for HS 18 commodities are factors that support the export performance of Indonesian agricultural products in China's destination market. Increased global demand and competitive composition effects for HS commodities 03 and 18, as well as increased global demand for HS 09 and HS 24 commodities, influence the performance of agricultural exports to the United States destination market.

The terms of the trade war between China and the United States have a different impact on the competitiveness of Indonesia's agricultural export products (shows in periode 3 and 4). Indonesia's agricultural product exports are growing better than the Chinese market in the destination country of the United States. The growth is indicated by the large number of Indonesian agricultural export commodities included in the "Rising Star" category on the market of the destination country of the United States. It can therefore be said that the conditions of this trade war have a significant impact on the export of Indonesian agricultural products to the United States market compared to the Chinese market.

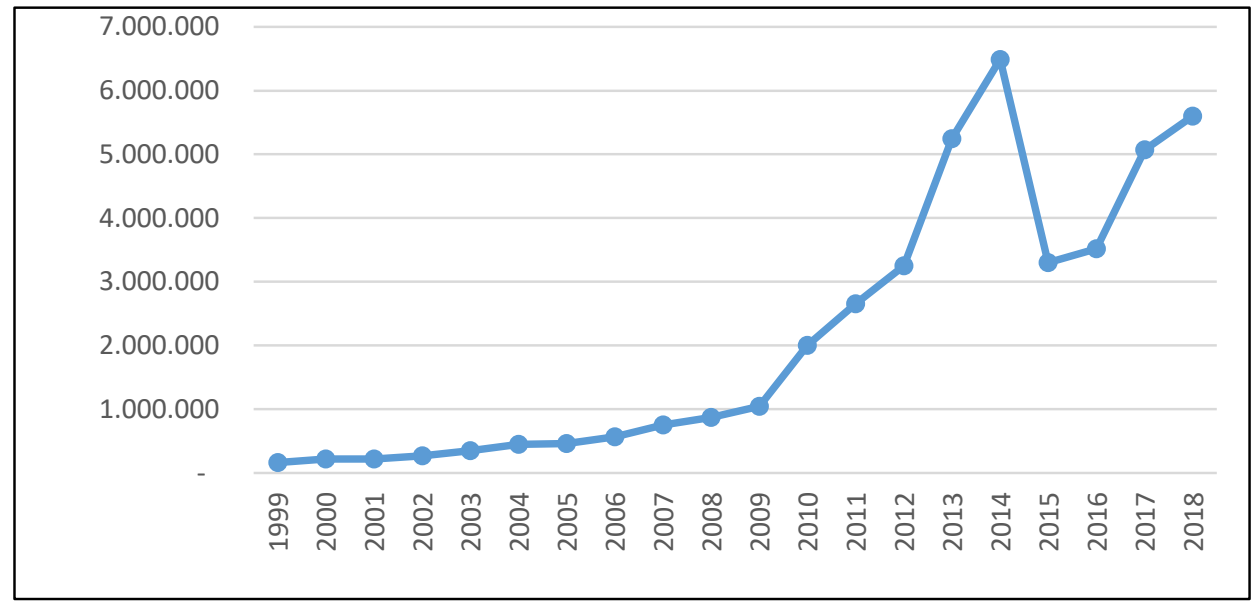

Source: [6]

Fig. 5. Growth of export product HS 04 from Rest of world to US from 1999 to 2018 (in thousand US\$)

The export performance of Indonesian agricultural products to the United States Destination Market improved during the trade war (period 4) compared to the previous period. Improving the performance of agricultural exports to the destination country is due to various factors, such as 
increased global demand, the composition of competitiveness and the impact of competitiveness. Commodities with improved competitive positions during the trade war were HS 01, HS 03, HS 04, HS 08, HS 12 and HS 18. Six agricultural export commodities experienced an increase in their competitive position from the previous period of 3 . Factors which influence the improvement of the competitive performance of agricultural commodities HS 01, HS 03, HS 12 and 18 are factors which influence the competitive composition of agricultural commodities. In the meantime, for agricultural commodities, HS 04 is influenced by increased global demand (Figure 5).

In the export markets of China, the competitiveness of Indonesia's agricultural exports is more stable, both in the days before and during the trade war. The goods in the Chinese market with good competitiveness are HS 04, HS 14 and HS 18. Good performance of exports of HS 04 commodity by competitiveness, HS 14 by competitiveness and HS 18 by increasing global demand (Figure 6).

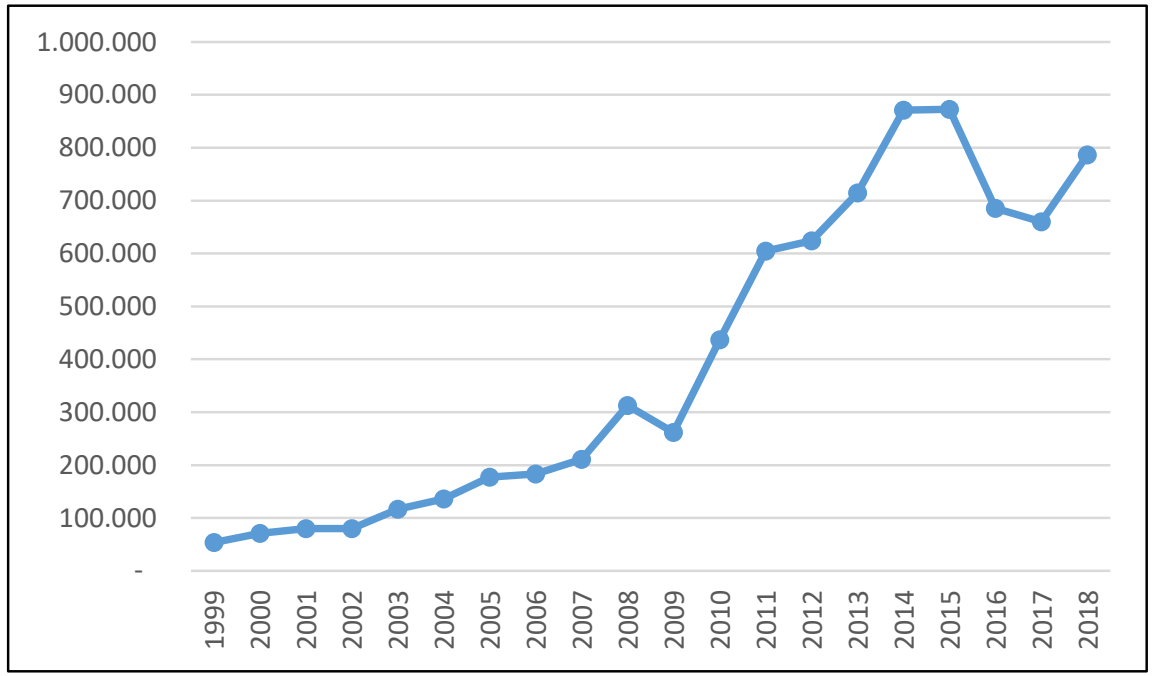

Source: [6]

Fig. 6. Growth of export product HS 18 from Rest of world to China from 1999 to 2018 (in thousand US\$) 
E3S Web of Conferences 232, 02001 (2021)

ICOnARD 2020

Table 2. Value of NRCA, EPD, and CMS between Indonesia and China every period

\begin{tabular}{|c|c|c|c|c|c|c|c|c|c|c|}
\hline \multirow{3}{*}{$\begin{array}{c}\text { HS } \\
\text { Code }\end{array}$} & \multicolumn{5}{|c|}{ Period 1} & \multicolumn{5}{|c|}{ Period 2} \\
\hline & \multirow[b]{2}{*}{ NRCA } & \multirow[b]{2}{*}{ EPD } & \multicolumn{2}{|r|}{ CMS } & \multirow[b]{2}{*}{$\mathrm{CE}$} & \multirow[b]{2}{*}{ NRCA } & \multirow[b]{2}{*}{ EPD } & \multicolumn{2}{|r|}{ CMS } & \multirow[b]{2}{*}{$\mathrm{CE}$} \\
\hline & & & WDE & $\mathrm{CCE}$ & & & & WDE & $\mathrm{CCE}$ & \\
\hline 01 & 0.00000091 & Retreat & 15.94 & -50.98 & 34.69 & -0.00000130 & Rising Star & 3.81 & -3.12 & -0.68 \\
\hline 03 & 0.00016927 & Retreat & 962.35 & $-1,908.83$ & 937.02 & 0.00002854 & Lost Opportunity & $1,370.24$ & $-1,433.89$ & 63.01 \\
\hline 04 & -0.00000950 & Retreat & 1.62 & -2.77 & 1.14 & -0.00000703 & Rising Star & 3.22 & 17.97 & -20.98 \\
\hline 07 & 0.00003001 & Retreat & 170.73 & -386.21 & 213.33 & 0.00001465 & Rising Star & 379.79 & -119.91 & -257.28 \\
\hline 08 & -0.00000175 & Retreat & 81.63 & -261.36 & 177.93 & -0.00000550 & Rising Star & 62.72 & 35.40 & -97.14 \\
\hline 09 & 0.00000783 & Falling Star & 29.72 & 36.35 & -65.42 & 0.00000318 & Lost Opportunity & 73.99 & -75.71 & 1.70 \\
\hline 12 & -0.00012100 & Falling Star & 24.00 & 35.90 & -59.30 & -0.00011896 & Rising Star & 196.12 & 490.10 & -679.35 \\
\hline 14 & 0.00001684 & Falling Star & 70.10 & 175.48 & -243.13 & 0.00001527 & Rising Star & 281.40 & -111.70 & -168.00 \\
\hline 18 & 0.00004465 & Retreat & 162.53 & -231.99 & 68.77 & 0.00003012 & Rising Star & 502.26 & 76.24 & -572.71 \\
\hline 24 & -0.00000806 & Retreat & 1.17 & -0.66 & -0.50 & -0.00000497 & Rising Star & 5.15 & 58.19 & -62.72 \\
\hline
\end{tabular}

\begin{tabular}{|c|c|c|c|c|c|c|c|c|c|c|}
\hline \multirow{3}{*}{$\begin{array}{l}\text { HS } \\
\text { Code }\end{array}$} & \multicolumn{5}{|c|}{ Period 3} & \multicolumn{5}{|c|}{ Period 4} \\
\hline & \multirow[b]{2}{*}{ NRCA } & \multirow[b]{2}{*}{ EPD } & \multicolumn{2}{|r|}{$\mathrm{CMS}$} & \multirow[b]{2}{*}{$\mathrm{CE}$} & \multirow[b]{2}{*}{ NRCA } & \multirow[b]{2}{*}{ EPD } & \multicolumn{2}{|r|}{ CMS } & \multirow[b]{2}{*}{$\mathrm{CE}$} \\
\hline & & & WDE & $\mathrm{CCE}$ & & & & WDE & CCE & \\
\hline 01 & -0.00000236 & Rising Star & 1.10 & 13.35 & -14.31 & -0.00000240 & Rising Star & 5.06 & 3.77 & -8.74 \\
\hline 03 & 0.00004741 & Rising Star & $1,084.99$ & $3,198.01$ & $-4,240.17$ & 0.00011412 & Lost Opportunity & $1,709.03$ & $2,127.87$ & $-3,798.54$ \\
\hline 04 & -0.00001779 & Lost Opportunity & 36.14 & -53.59 & 17.28 & 0.00000313 & Rising Star & 668.42 & $2,140.30$ & $-2,780.63$ \\
\hline 07 & 0.00000062 & Lost Opportunity & 372.92 & -115.81 & -254.54 & -0.00000533 & Lost Opportunity & -31.14 & -210.94 & 239.67 \\
\hline 08 & -0.00001333 & Lost Opportunity & 108.61 & -2.91 & -104.64 & -0.00000434 & Rising Star & 635.32 & 278.36 & -904.55 \\
\hline 09 & 0.00001166 & Rising Star & 206.31 & 375.45 & -575.95 & 0.00001864 & Lost Opportunity & 323.64 & -617.71 & 291.13 \\
\hline 12 & -0.00018524 & Rising Star & $1,020.02$ & 988.04 & $-1,987.98$ & -0.00017112 & Rising Star & 434.73 & 223.07 & -651.23 \\
\hline 14 & 0.00001172 & Lost Opportunity & 373.15 & -723.56 & 346.91 & 0.00000062 & Rising Star & 6.81 & -15.52 & 8.63 \\
\hline 18 & 0.00003716 & Lost Opportunity & 698.82 & -516.54 & -180.46 & 0.00003566 & Rising Star & 541.68 & 91.82 & -627.17 \\
\hline 24 & -0.00000456 & Rising Star & 88.89 & 31.19 & -118.88 & -0.00000902 & Lost Opportunity & -47.67 & -115.15 & 161.19 \\
\hline
\end{tabular}


Table 3. Value of NRCA, EPD, and CMS between Indonesia and US every period

\begin{tabular}{|c|c|c|c|c|c|c|c|c|c|c|}
\hline \multirow{3}{*}{$\begin{array}{l}\text { HS } \\
\text { Code }\end{array}$} & \multicolumn{5}{|c|}{ Period 1} & \multicolumn{5}{|c|}{ Feriod 2} \\
\hline & \multirow{2}{*}{ NRCA } & \multirow{2}{*}{ EPD } & \multicolumn{3}{|c|}{ CMS } & \multirow{2}{*}{ NRCA } & \multirow{2}{*}{ EPD } & \multicolumn{3}{|c|}{ CMS } \\
\hline & & & WDE & $\mathrm{CCE}$ & $\mathrm{CE}$ & & & WDE & $\mathrm{CCE}$ & $\mathrm{CE}$ \\
\hline 01 & -0.00001028 & $28 \quad$ Falling Star & 0.32 & 2.52 & -6.87 & -0.00000700 & Lost Opportunity & 9.84 & -7.44 & -1.76 \\
\hline 03 & 0.00018605 & $05 \quad$ Falling Star & 241.19 & $1,753.01$ & $-4,926.20$ & 0.00024113 & Rising Star & $5,163.80$ & $2,111.86$ & $-5,437.82$ \\
\hline 04 & -0.00000298 & $98 \quad$ Falling Star & 1.05 & 52.35 & -61.29 & -0.00000112 & Rising Star & 83.86 & 9.09 & -17.54 \\
\hline 07 & -0.00001463 & 63 Retreat & -0.24 & -3.10 & 6.56 & -0.00001549 & Lost Opportunity & 21.83 & -16.55 & 6.50 \\
\hline 08 & -0.00002123 & 23 Retreat & 16.72 & -84.68 & -154.84 & -0.00001896 & Rising Star & 71.46 & 76.64 & -23.19 \\
\hline 09 & 0.00008529 & 29 Retreat & 209.53 & -469.05 & $-2,909.62$ & 0.00009957 & Rising Star & $2,012.33$ & $1,684.94$ & $-5,745.66$ \\
\hline 12 & -0.00000307 & Retreat & 4.15 & 9.78 & -24.45 & -0.00000274 & Lost Opportunity & 29.44 & -21.22 & 18.42 \\
\hline 14 & 0.00000008 & 08 Retreat & 4.01 & -15.95 & -19.28 & 0.00000031 & Lost Opportunity & 11.18 & -1.25 & 17.28 \\
\hline 18 & 0.00012798 & 98 Retreat & 486.91 & $-1,538.50$ & -494.42 & 0.00010019 & Rising Star & $2,041.11$ & 573.65 & 343.38 \\
\hline 24 & 0.00000369 & 69 Retreat & 22.86 & -60.04 & -211.94 & 0.00000563 & Rising Star & 185.92 & 115.69 & -63.04 \\
\hline \multirow{3}{*}{$\begin{array}{l}\text { HS } \\
\text { Code }\end{array}$} & \multicolumn{5}{|c|}{ Period 3} & \multicolumn{5}{|c|}{ Period 4} \\
\hline & \multirow{2}{*}{ NRCA } & \multirow{2}{*}{ EPD } & & CMS & & \multirow{2}{*}{ NRCA } & \multirow{2}{*}{ EPD } & \multirow{2}{*}{\multicolumn{2}{|c|}{ CMS }} & \multirow[b]{2}{*}{$\mathrm{CE}$} \\
\hline & & & WDE & CCE & $\mathrm{CE}$ & & & & & \\
\hline 01 & -0.00000766 & Lost Opportunity & 3.52 & -5.15 & -1.58 & -0.00000878 & Rising Star & 2.01 & 15.16 & $-1,499.88$ \\
\hline 03 & 0.00030633 & Rising Star & $2,413.56$ & $2,484.74$ & $-11,275.40$ & 0.00046398 & Rising Star & $3,746.11$ & $4,233.41$ & $1,647.80$ \\
\hline 04 & -0.00000116 & Lost Opportunity & 98.11 & -85.19 & -92.26 & -0.00000271 & Rising Star & 40.74 & 23.97 & -41.06 \\
\hline 07 & -0.00002397 & Lost Opportunity & 5.41 & -1.73 & -12.60 & -0.00002900 & Lost Opportunity & 5.56 & -17.25 & 77.78 \\
\hline 08 & -0.00003081 & Rising Star & 26.32 & 83.54 & -282.12 & -0.00004049 & Rising Star & 82.94 & 75.21 & 390.94 \\
\hline 09 & 0.00015897 & Lost Opportunity & $1,420.71$ & 349.51 & $2,172.82$ & 0.00015993 & Lost Opportunity & $1,436.08$ & -924.05 & 563.09 \\
\hline 12 & -0.00000555 & Lost Opportunity & 18.50 & -39.73 & -141.16 & -0.00000562 & Rising Star & 16.88 & 192.09 & -30.45 \\
\hline 14 & -0.00000005 & Lost Opportunity & 0.89 & -13.17 & 6.28 & -0.00000025 & Lost Opportunity & 0.53 & 0.00 & -266.49 \\
\hline 18 & 0.00011197 & Lost Opportunity & $2,323.84$ & $-4,623.00$ & $-3,173.90$ & 0.00010344 & Rising Star & 775.98 & $3,068.15$ & -747.35 \\
\hline 24 & 0.00000669 & Lost Opportunity & 145.22 & -97.62 & 107.93 & 0.00000254 & Lost Opportunity & 82.27 & -294.19 & 30.76 \\
\hline
\end{tabular}




\section{Conclusions}

Based on the results of the debate, it can be concluded that trade war conditions between China and the US affect Indonesia's agricultural products' competitiveness and competitiveness in that countries of destination. Indonesia's export agricultural commodities to the countries of destination of China and the United States during the trade war are: HS 01, HS 04, HS 08, HS 12 and HS 18. The main factors influencing the competitiveness of Indonesian agricultural exports to China and the US are the growth in global demand and the composition of competitiveness.

\section{References}

1. H. Timmons, Reuters (2020).

2. B. A. Bovino and S. Roache, S P Glob. (2019).

3. M. Li, W. Zhang, and C. Hart, JSTOR 33, 1 (2014).

4. C. P. Bown, Peterson Inst. Int. Econ. (2020).

5. M. of T. Republic of Indonesia, Stat. Perdagangan-Ekspor Impor Indones. (2020).

6. UNCOMTRADE, Int. Trade Stat. (2020).

7. R. Yu, J. Cai, and P. S. Leung, Ann. Reg. Sci. 43, 267 (2009).

8. A. Pradipta and D. M. Firdaus, J. Manaj. Agribisnis 11, (2014).

9. B. M. Hoekman, P. English, and A. Mattoo, Development, Trade, and the WTO: A Handbook (The World Bank, 2002).

10. D. Esterhuizen, An Evaluation of the Competitiveness of the South African Agribusiness Sector (University of Pretoria, 2006).

11. H. Tyszynski, Manchester Sch. 19, 272 (1951).

12. R. Baldwin, Rev. Econ. Stat. 40, 50 (1958).

13. S. Spiegelglas, Manchester Sch. Econ. Soc. Stud. 27, 111 (1959).

14. S. Naya, Econ. Dev. Cult. Change 15, 420 (1967).

15. E. E. Leamer and R. M. Stern, Quantitative International Economics (Transaction Publishers, 1976).

16. M. Okabe and S. Urata, J. Asian Econ. 35, 12 (2014).

17. L. Sugiharti, R. Purwono, and M. A. E. Padilla, Entrep. Sustain. Issues 7, 2676 (2020).

18. I. Inayah, O. Rina, and K. D. Heny, Int. J. Sci. Res. 5, 1856 (2015).

19. H. Schaak, The Impact of Free Trade Agreements on International Agricultural Trade: A Gravity Application on the Dairy Product Trade and the ASEAN-China-FTA (2015).

20. J. Tampubolon, WSEAS Trans. Bus. Econ. 16, 120 (2019).

21. Y. Nugrahaningrum, R. Zakaria, and F. Fahma, in AIP Conf. Proc. (AIP Publishing LLC, 2020), p. 30067.

22. T. N. Ramadhani and R. P. Santoso, Econ. J. Emerg. Mark. 11, 46 (2019).

23. J. F. R. SJ and S. Roy, Procedia-Social Behav. Sci. 133, 336 (2014).

24. M. Pangestu, China Econ. J. 12, 208 (2019). 